\title{
Changes in Stadium Sports Spectators Customer Experiences
}

\section{A stadionokba járó nézók vásárlóélményeinek változásai}

\author{
Ekaterina Glebova1,2, Michel Desbordes ${ }^{1,2}$, Gabor Geczi $^{3}$
}

1 Université Paris-Saclay CIAMS, 91405, Orsay, France

2 Université d'Orléans, CIAMS, 45067, Orléans, France

3 University of Physical Education, Budapest, Hungary

Abstract - Over the centuries, in most countries of the world, stadiums have changed and evolved, and with it, the behaviour and ways of experience of their visitors and spectators have certainly transformed. With improvements in-home entertainment systems and internet connectivity occurring all the time, sports fans have a greater capacity to build themselves a viewing experience that fits their preferred specifications, right in the comfort wherever they are: airplane, hotel, office, or their own room. Subsequently, sports stadiums are in the process of challenge and technological evolution, including implementation of various innovations. It attempts to create smooth, strong impressive experience and appeals to attract spectators out of their mediatory watching and to bring them into the stadium, wherever it is situated. In the current paper we investigate and review the critical areas and identify the phenomena of transformations addresses to deliver a next-generation stadium experience that is affective enough to compete with the cost, comfort, impressions benefits of "mobile" spectatorship (Thomson, Potter, 2017). A multidimensional content analysis (Tharenou, 2010) of collected data let us outline the key area of stadium technological transformation, referring to the customer-centric approach (McAlexander et al., 2002; Zaky \& Neely, 2018). We define and outline the key areas of changes in SSCX in order to better predict their nature, courses and impact, projecting future perspective research directions.

Keywords: sport stadium, customer experience, new technologies, Internet, fan applications, connected stadium

\begin{abstract}
Absztrakt - Az elmúlt évszázadok során a legtöbb ország stadionjai változtak, fejlődtek, és ezzel párhuzamosan a látogatók és a nézók viselkedése és tapasztalatai is nagy átalakuláson mentek keresztül. Az otthoni szórakozást támogató rendszerek és az internetkapcsolat állandósága azt hozta magával, hogy a szurkolóknak nagyobb mozgástere van abban, hogy saját maguk számára kialakítsák azt az élményt, amely igazodik saját preferenciáikhoz, és elérhetó bárhol, ahol szeretnék, repülő́n, szállodában, irodában, vagy éppen saját otthonukban. Következésképpen a sportstadionok üzemeltetói számos kihívással szembesülnek, és a technológiai fejlődés különbözó innovációs folyamatokat hív életre. Céljuk egy gördülékeny, ugyanakkor erős szurkolói élmény létrehozása, amely elég vonzó ahhoz, hogy a médián keresztüli fogyasztás helyett a stadionba vigye a szurkolókat, bárhol is legyen a helyszín. Jelen tanulmányban vizsgáljuk és áttekintjük azokat a kritikus területeket és változási folyamatokat, amelyeken keresztül létrehozhatóvá válik az az új generációs stadion-élmény, amely hatékonyan tudja felvenni a versenyt a „távoli” szurkolás költségeivel, kényelmével és elónyeivel (Thomson és Potter, 2017). A gyújtött adatok multidimenzionális tartalomelemzése (Tharenou, 2010) nyomán felvázoljuk a stadionok technológiai átalakulásának föbb területeit, a vásárlóközpontú megközelítés szempontjából (McAlexander et al., 2002; Zaky \& Neely, 2018). A sport stadionok átalakulásának kulcsterületeinek számba vétele és meghatározása lehetóvé teheti a jövőbeli fejlódési perspektvák és hatások, illetve a lehetséges kutatási irányok felvázolását.
\end{abstract}

Kulcsszavak: sport stadion, vásárlóélmény, új technológiák, Internet, szurkolói applikációk, digitális stadion 


\section{Introduction}

Stadiums in sports are comparable with churches in religion: it's one of the key concepts in industry. Religion is abstract and it could exist without churches, likewise sports could exist without stadiums. But both of these concepts signify the physical places which unite people to follow their passion and pursue their interests.

The history of stadium begins in ancient Greece and Rome or even earlier. And over the centuries, in most countries of the world, stadiums have changed and evolved, and with it, the behaviour and ways of experience of their visitors and spectators have certainly transformed. Since ancient times, stadiums are a place of worship for sports fans. From the original structures of antiquity, they have turned into the most impressive objects of engineering and design, in the arenas of which not only sports events are held, they become the main venue for grandiose concerts and cultural events and the crucial part of urban infrastructure. We consider stadium as an adaptor of the current state of evolution in society and technological development (Glebova \& Desbordes, 2021). With improvements of in-home entertainment systems and internet connectivity occurring all the time, sports fans have a greater capacity to build themselves a viewing experience that fits their preferred specifications, right in the comfort wherever they are: airplane, hotel, office, or their own room: "Compelling remote viewing experiences mean greater competition for venues. Venues need to work even harder to get people to live events, so we can see a trend for new technology to help create super fan experiences inside the stadium. Stan Ross, a Thought Gallery contributor on behalf of NAB Show, describes how at Wembley Stadium, the arch across the center of the stadium now has an integrated lighting system that responds to the game's biggest moments and a live arch camera running on the app that adds even more event engagement" (Nicholas Brice).

Subsequently, sports stadiums are in process of technological challenge in order to create strong impressive experience and to attract spectators out of their mediatory watching and to bring them into the stadium, wherever it is situated. This paper intends to review the critical areas and identify the phenomena of transformations addresses to deliver a next-generation stadium experience that is affecting enough to compete with the cost, comfort, impressions benefits of "mobile" spectatorship (Thomson \& Potter, 2017).

New technologies provide new opportunities to enhance customer experience (CX) in stadiums and beyond. In today digital world sport industry organizations needs to be connected with sports spectators, fans and customers in order to create, manage and improve relationships (Sheth, 2002). The proliferation and infusion of rapidly advancing technologies have attracted much attention from both research and industry, and fundamentally changed the way customers and service field communicate and interact (Lee \& Baker, 2017). With the rapid development of technology, it is obvious that sports industry is undergoing many metamorphoses and fundamental changes that affect all aspects of sports consumption (Gulhane, 2014), marketing and management.

The use of technological applications is now widespread all over the world by all sport fans, teams, brands, associations, coaches and athletes and the adoption of these tools to gain a 'competitive advantage' is an increasingly important feature of sports (Giblin et al., 2016). Consumer habits and technology development are becoming major drivers of change in sports industry, bringing on one hand uncertainty and on the other hand new marketing opportunities.

This paper aims to define and outline the key areas of changes in Sport Spectators Customer Experiences (SSCX) in order to better predict their nature, courses and impact. It can be utilized by sport managers in order to deliver better SSCX and stadium service offers.

\section{Theoretical background}

Similar questions are actively discussed in the sports management professional communities and recent thematic events (Stadium Managers Association, World Stadium Congress 2019, Horizon Sports Summit 2019, Sports Facilities and Franchises and Ticketing symposium; European Association for Sport Management conference 2020, etc.). However, it has not achieved to build the structured list of stadium SSCX transformations brought by technological development and properly outline fields of changes.

The development of connected stadiums has become a primary requirement to improve the 
customer experience (Jäger, 2013; Schut \& Glebova, 2020). By offering additional services and deploying an adapted marketing strategy (Bal \& Fleck, 2016), stadiums must become more profitable.

This study is focused on the intersection of four concepts (Figure 1):

- Stadium

- Technology

- Sport Spectacle (SS)

- Customer Experience (CX)

\section{Stadium}

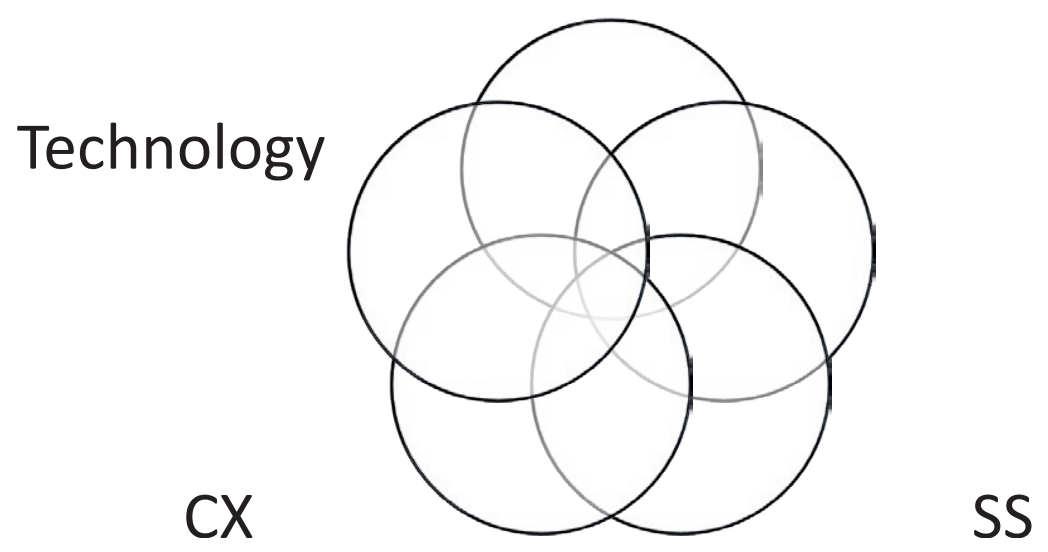

Figure 1. Identifying the study focus

Over the years scholars described the importance of communicating with customer ( $\mathrm{Yu}$ \&Trail, 2011), including sports industry (Bee \& Khale, 2006; Abeza et al., 2013). We have noticed that diffusion of technologies have changed the way how fans and sports service field communicate and interact (Glebova \& Desfontaine, 2020).

Obviously sport spectators experiences are not the same. Indeed, scholars have proposed over the years a number of customers and CX typologies, or ways to classify CX. By distinguishing among many typologies of CX, we can better predict their nature, courses and impact. Defining and improving customer experience is still important for industry and academic research because experience has replaced quality "as the competitive battleground for marketing" (Klaus \& Maklan, 2012). Accordingly, examining patterns of sport consumption (experience practices) allow to identify interesting cognitive and affective differences between customers, revealing subtle nuances that people bring to their sport consumption experiences (Stewart et al., 2003; Hautbois et al., 2019).

Shank (2005) distinguished three distinct types of consumers: spectators, participants and sponsors the sport industry intends to satisfy the needs of. Accordingly, the current chapter is focusing on spectators, however taking into account the interests of all stakeholders.

Nass (2016) defines five design principles of 'the experience economy': 1) theme the experience, 2) harmonize impressions with positive cues, 3) eliminate negative cues, 4) mix in memorabilia and 5) engage the senses. Based on these principles Nass (2016) offered a framework for improving spectator experiences at the service parks of the FIA World Rally Championship (WRC) events and concluded that "service parks would benefit from a coherent adaptation to five design principles of the experience economy".

Traditionally, tools such as customer feedback surveys, questionnaires and interviews are used as a method of measuring customer satisfaction and a company's future performance (Morgan $\&$ Rego 2006). Zaki and Neely (2018) argued that "traditional" tools are used at the end of the customer experience journey, masking the underlying issues of concern, which form the basis for identifying improvements.

In 2007 Gentil et al. suggested that a customer's subjective response is multifaceted (rational, 
emotional, sensorial, physical, and spiritual). In 2009 Verhoef et al. noted "total experience" included "search, purchase, consumption, and aftersale phases of the experience". Later, in 2016 these ideas were continued and developed on work of Lemon and Verhoef. In 2011 Lemke has offered a conceptual model of CX based on 3 main encounters: communication, service and usage.

Finally it was concluded that there are many challenges to conducting research in this area and the field of customer experience management is a relatively new "greenfield" area for future research (Lemon \& Verhoef, 2016).

Hence, Lemon and Verhoef have mentioned that $\mathrm{CX}$ is a fundamental factor in marketing, accordingly, many empirical findings have suggested a link between CX and business outcomes economic value, loyalty, satisfaction, profit, (re) purchasing decision etc. According to Gilmore and Pine (2002), customers need something more than quality service. They are looking for interesting and significant experience.

Using a stakeholder theory the study of Biscaia et al. (2018) provides the first exploration of fan identity as a multidimensional construct, indicating acceptable psychometric properties of the multidimensional construct of fan identity composed of power, urgency, internal and external legitimacy. Power and internal legitimacy were significantly related to the intentions to attend more games and to purchase merchandise, with internal legitimacy also influencing intentions to recommend games to others.

\section{Methodology, Design, Approach}

This is an exploratory study. It draws attention on literatures spanning from emerging technology, CX (customer experience), stadium experiences and combine them with data collection and analysis from observations, interviews $(\mathrm{N}=5)$ with international sport management and technology experts (Table 1), the current official websites (stadiums, sport venues, facilities, management and technological companies) (see the list of web references) in the spirit of grounded theory (Glaser \& Strauss, 1967). Unstructured open-ended interviews have been conducted on Skype and messenger and lasted 30-40 minutes. We used the purposive sample of experts regardless of their demographical characteristics: (1) professional in sport management or sport marketing, (2) English-speaking, (3) expertise in sport management and technology fields. In order to better deliver experts' opinions to a reader, we partially use interviewees verbatim to explain how new technologies change the experiences of sports spectators customer (SSCX) in modern stadiums.

Table 1: List of interviewees

\begin{tabular}{|c|c|c|l|}
\hline$\#$ & Name & Location & Short Bio \\
\hline 1. & $\begin{array}{c}\text { Nicholas } \\
\text { Brice }\end{array}$ & UK & 360 degree vision, coach and consultant \\
\hline 2. & $\begin{array}{c}\text { Ciprian- } \\
\text { George } \\
\text { Enache }\end{array}$ & $\begin{array}{c}\text { Bucharest, } \\
\text { Romania }\end{array}$ & $\begin{array}{l}\text { Marketing Director at Digital Economy Development, Marketing } \\
\text { Communications Specialist at International Motors Group, an } \\
\text { authorized dealer for Kia Motors, Isuzu D-Max, Alfa Romeo, Jeep, } \\
\text { Fiat and Fiat Professional }\end{array}$ \\
\hline 3. & Juan Iraola & $\begin{array}{c}\text { Madrid, } \\
\text { Spain }\end{array}$ & Head of Digital Transformation - Technology at Real Sociedad \\
\hline Stijn Jacobs & Paris, France & $\begin{array}{l}\text { Founder of What's Next Consulting - Consultancy focused on } \\
\text { digitalization and innovation }\end{array}$ \\
\hline 5. & $\begin{array}{c}\text { Ryan } \\
\text { McCumber }\end{array}$ & NY, USA & $\begin{array}{l}\text { Founder of SportsTech.ai and FIST Global Series, Board Member } \\
\text { Strategic Advisor and Global Connector Sportstech and Esports }\end{array}$ \\
\hline
\end{tabular}


An iterative multidimensional content analysis (Tharenou, 2010) of collected data let us outline the key area of stadium technological transformation, referring to the customer-centric approach (McAlexander et al., 2002; Zaky \& Neely, 2018). The thematic six-step analysis in this study was truly an iterative and continual process. First, we are engaged in indwelling, transcribed the interviews verbatim, read the transcripts a few times, created short synopses of the participants' insights and revised them, consulting with the official websites of the mentioned companies. Second, the transcripts were re-read again to identify dominating themes, outlining the key transformations in stadium SSCX. Furthermore, we disclosed and described each point of transformation, based on collected data in holistic manner referring to the customer-centric perspective (Chavanat \& Bodet, 2014).

\section{Discussion and Results}

Iterative data analysis of primary and secondary collected data let us outline the key areas of stadium technologies implementation in order to enhance SSCX.

\section{Stadium Flexibility: Multi-purposes smart stadiums, multi-functional nature facilities}

Stadiums are no more just a sporting venue but a multi-purpose (Chub \& Kreizer, 2020) and an essential part of the community and the city too. Multi-purpose nature of stadiums gives an opportunity to the marketing professional to convert non-sporting fans to customers of the future and creating a loyal and engaged fan base.

AT\&T (official name of the facility) stadium ${ }^{1}$ is the perfect example of a multi-functional facility. On its own premises it offers a variety of tours, hotel accommodation, and contemporary art museum, shows, concerts, and sports events as well.

Strahov Stadium is a case of total transformation of nature of facility, is a stadium which is no longer used for competitive sports events (just large concerts with capacity of 220,000, including 56,000 seated).

\section{Modular stadium infrastructure: stadium smart flexibility}

In the past, many mega spots events have been notorious for leaving "White elephants" expensive, underutilized and abandoned infrastructure (Solberg, 2014) but recently this trend seems to be coming to a halt as Rio de Janeiro constructed many of its stadiums with prefabricated modular parts that can be easily disassembled, moved to a new location and then reconfigured into community sports facilities.

New stadiums are supposed to implement modular infrastructure which allows them to temporarily provide extra seating capacity and flexible equipment. Once each key event is over, the modular seating/facilities/equipment can be dismantled and stored. One such stadium is the AT\&T Stadium, which is listed as having a seating capacity of 80,000 , but apparently it is expandable to 105,000 with standing area.

Qatar is preparing modular seating for many of its FIFA World Cup stadium, including the 60,000-seat Al Bayt Stadium in Doha, which will have its capacity reduced to 32,000 after the tournament ${ }^{2}$.

It straightens the multi-purpose nature of facility, because modular structures let temporary modify stadium assignment and use it "for other purposes".

\section{Providing comfort environment: Seating, Temperature/Humidity/ Air Conditioning and Weather Controlling Technologies}

Providing performers and fans with a comfortable environment to perform and spectate is of profound importance. The problem is particularly pressing for stadiums located in countries with very hot or cold climates, which make implementation HVAC (heating, ventilation, and air-conditioning) solutions necessary.

For an example, Qatar has already enjoyed widespread success with the testing of advanced HVAC technologies due to be installed in the FIFA World $\mathrm{CUP}^{3}$ stadium already under construction. Qatar announces Lusail Stadium ${ }^{4}$ an open-air but conditioning stadium as well.

\footnotetext{
${ }^{1}$ https:/lattstadium.com

${ }^{2}$ https://www.sc.qalen/stadiums

${ }^{3}$ https://www.fifa.com/worldcuplqatar2022/

${ }^{4}$ https://sc.qalen/stadiums/lusail-stadium
} 
The finals will start in November 2022, having been moved from the usual June-July slot to avoid the over 40-degrees summer heat. HVAC innovations are announced on Qatar World Cup in order to combat Qatar's high temperatures which are often in over 40 degrees Celsius. This will give the facility 365-days-a-year usability and enhance the multi-purpose nature of the stadium, making SSCX more comfortable.

How HVAC improves SSCX:

- Gives the facility all-year-round usability

- Enhances multi-purpose nature of stadium

- Extends opportunities for monetization

- Increases level of comfort for visitors

The convenience of chairs is basic and essential for SSCX. Nowadays stadiums implement in-seat charging points, improved way-finding with inseat lighting for row and seat numbers, larger seating space. The functions of seat temperature control, installed audio and interfaces in the seat are a kind of emerging field: "Companies such as Mixhalo enable live event organizers to deliver highquality, real-time audio directly to attendees' own phones and headphones, giving every seat access to a better audio experience. A new type of premium seating is also on offer, where small 'pods' of seats are mounted on rails that slowly move around the venue during the event. A fully 360-degree view! Tunnel clubs are emerging too in sports venues, giving premium customers the chance to see players up close and personal arriving for the match. Venues such as Brooklyn's Barclays Center have installed digital screens to keep fans informed about starting times and train schedules (a subway station is outside), as well as to deliver highlight video on the big screens." (Nicholas Brice).

\section{Access, Smart Ticketing Systems, Security, Safety Improvements}

Stadiums are an essential point of any community or city and usually attract millions of visitors each year.

Screening solutions and police presence are parts of many sports events. But increased waiting time to enter the stadium hurts SSCX. Coupled with advancement in broadcasting and digital technology, fans can easily stay away from stadiums and still enjoy the matches in full digital clarity, all in the comfort of their home.

The key innovation is the placement and operation of advanced security camera technologies along with an identification functions, including automatic face recognition, centralizing security management. For example, Kyocera Stadium club cards include a chip for contactless access, so card holders can be accessed automatically. Cameras at the entrances of the stadium use "FaceR", facial recognition algorithm, to scan the faces of everyone who enters the facility 5 .

In terms of stadium access the crucial role plays in the location and transport infrastructure: "I went to stadium of Lyon, and we can find it as a sort of great stadium. Get out of the train station, there is a bus that takes you to the right place, everybody is organized and when you moving into a stadium you are fully connected and it's comfortable, interesting, and I think that's the minimum we should do and have providing live spectating experiences, I mean in general. There is about mobility, ecology, accessibility - there are main things need to be sent to attention today" (Stijn Jacobs).

Minnesota's U.S. Bank Stadium ${ }^{6}$ is a leading example of this approach as it deploys sixty-five 16-megapixel cameras that have high enough quality for an operator to read large text on a fan's t-shirt or placard ${ }^{7} .300$ additional Samsung cameras are placed along stadium concourses and the security control room features a platform that integrates data from live video feeds, sensors, weather stations and all monitoring equipment covering the stadium and each of its 365 doors (Ritchy, 2017).

FIFA World Cup Local Organizing Committee with the professional Russian public organization in the field of sustainable construction in their report (2018) emphasizes the Importance of Access for people with limited mobility, including all the required structures and equipment and special labels, and signs for navigation.

Obviously, using human agents to check manually every fan's ticket upon entry is an inefficient and costly methodology, which is why more stadiums are investing in smart/automatic ticketing systems. Today widespread QR codes are examples

${ }^{5}$ https://tkhsecurity.com/case/kyocera-stadium-ado-den-haag/

${ }^{6}$ https://www.usbankstadium.com/

${ }^{7}$ https://www.vikings.com/news/u-s-bank-stadium-views-on-high-tech-cameras-soar-15930234 
how that technology can improve organizational performance (Melián-González \& Bulchand-Gidumal, 2016) and employees' performance and satisfaction (Jeong et al., 2016). Prior research suggests that technology in services results in positive outcomes including firm performance (MeliánGonzález \& Bulchand-Gidumal, 2016), behavioural intentions and customer retention (Lee\& Baker, 2017). By deploying fully automated ticket control, validation and payment solutions, stadium managers can ensure that fans with authentic tickets enjoy quicker "smooth" access to the venue (Kaiser et al., 2019).

As an additional benefit, these technologies reduce operational costs and increase revenue at point of-sale ticket booths, while also combating "ticket touts/scalps" who often may sell invalid or over-priced tickets.

3D technologies enhance SSCX even on the stage of buying ticket. It is not a unique example, but friendly to innovations, FC Barcelona ${ }^{8}$ has implemented ticketing $3 \mathrm{~d}$ technology ${ }^{9}$, which allows preview pf a potential seat view and specification in the immersive $3 \mathrm{~d}$ mode.

\section{Social Media}

In terms of sports consumption social media is far from new, but essential because social aspect of fandom is crucial (Chavanat \& Bodet, 2014; Ha et al., 2016; Lemon \& Verhoef, 2016).

Furthermore, today Social Media goes far beyond just a "social" aspect of sports consumption, marketing and management, it's become a platform for almost full-cycle sports spectating (preproduction, production, post-production), embracing, covering and consolidating all the stages of fan interaction trough even various forms, tool and functions.

In the intersection with XR (immersive technologies), mobile apps, Internet connectivity, collaborations and outsourcing, safety, internet organization social media has become essential part of full-cycle stadiums (and non-stadiums as well) sports fans experiences.
FC Barcelona fans were given the immersive experience opportunity of the season in $360^{\circ}$ virtual reality. Collaboration between the FC Barcelona and Facebook used the latest Clásico to offer fans the chance to put themselves in various corners of the Camp Nou using virtual reality technology. On the game, different areas were equipped with Facebook's Oculus ${ }^{10}$, such as the tunnel before the players walk onto the field, allowing fans to enjoy a 360 degree experience. The content will be published on the club's official Facebook channel ${ }^{11}$.

FC Barcelona is the leader among sports clubs on the other social media outlets. On Instagram, they are about to surpass the 50 million mark; on its multiple Twitter accounts the club has reached 41 million followers; while on YouTube there are around three million subscribers. Among all the social media outlets, FC Barcelona leads the way with over 280 million active followers ${ }^{12}$.

\section{Fan Applications, Mobile and Immersive Experiences}

With the vast majority of fans bringing their own smartphone, wearable or internet-connected device to the game, stadium operators have a chance to connect with their audience, interact and engage them in ways unbelievable just a decade ago. Internet coupled with digital technologies brings numerous opportunities for all the stakeholders.

Virtual Reality technology (VR) is moving beyond the headset opportunities and shifting on a smartphone or on a giant replay screen on/inside the stadium (like the 360-degree halo screen being built into the roof of Atlanta's new Mercedes-Benz Stadium ${ }^{13}$ ). Augmented Reality (AR) provides an additional information to fans, including game analytics, stadium navigation or advertising (Glebova, 2020).

Levi's Stadium ${ }^{14}$ provides an app for fans to order food and drinks to their seat, watch the commercials during the match's forced commercial breaks and check the length of the queue for the bathrooms: "At Levi's Stadium, home to Super

\footnotetext{
${ }^{8}$ https://www.fcbarcelona.com/en

${ }^{9}$ https://3ddigitalvenue.com/platform/ticketing3d

${ }^{10}$ https://www.oculus.com/

${ }^{11}$ http://fcbusiness.co.uk/news/fc-barcelona-and-facebook-collaborate-on-360o-content/

${ }^{12}$ https://www.fcbarcelona.com/en/news/769894/fc-barcelona-reaches-100-million-facebook-fans

${ }^{13}$ https://mercedesbenzstadium.com/

${ }^{14}$ https://www.levisstadium.com/
} 
Bowl 50, fans can also get food and drinks delivered to their seats through the app, which even shows them the route to the least crowded toilet!" (Nicholas Brice).

Moreover, the app turned each fan's smartphone into a direct link to the in-stadium coverage, allowing them to access commentator broadcasts, pull up replays shot from four different camera angles and generally track the coverage in a more personalized manner, it demonstrates that providing an interactive, immersive experience can all be enhanced with state of the art technologies.

\section{Restoration / Eating out / Collaborations}

Restoration is the huge part of the service field and it significantly overlaps with stadium experiences. Developing of online food delivery services may deploy in-stadium restoration on-shore, because users can benefit from unlimited variety of choices. Accordingly, it may be a trend of effective outsourcing of restoration and catering in stadiums.

Postmates ${ }^{15}$ becomes the exclusive on-demand delivery and pickup partner of the Yankees and will integrate its recently-launched Postmates Live offering into concession stands at Yankee Stadium: "There are very simple but important things, such as accessibility, but also services that we have. For example, Uber delivers food home, and other delivery companies like Postmates bring drinks and food directly to your stadium seat. We need to avoid any waiting lines, thanks to technologies it became possible" (Stijn Jacobs).

According to the agreement, stadium visitors will be able to place their order from their seats and pick it up when it is ready at designated Postmates Pickup locations. Orders will not come with an added fee and this tool will help eliminate queuing at Yankee Stadium.

\section{Outsourcing}

Restoration is not the only one field managed by outsourcing. There are many other areas to be given to professional outsourcing companies: Tickets ${ }^{16}$, Security, Cleaning, Merchandising, Marketing, Pitch maintenance, CRM management etc. It's a crucial moment in terms of optimization strategy.
The Outsourcing Institute ${ }^{17}$ has outlined 10 benefits for implementing outsourcing solutions.

- Cost reduction and operations control;

- Improving company (facility) focus;

- Gaining access to the various possibilities;

- Free internal resources for other purposes;

- Resources are not available within the company;

- Accelerate the benefits reengineering;

- Driving is expensive for some time;

- Employment equity becomes available;

- Sharing risks;

- Capital injection. (Troacă \& Bodislav,2012)

All these points are applicable in stadium business.

\section{Internet and Stadium Connectivity: "Con- nected Stadiums"}

Mega sports events draw crowds that generate huge flow of internet (Wi-Fi, 3G, 4G) traffic as visitors may upload/download content, share the experience via personal devices and social media, staying in touch with their communities. As such, stadiums are developing the ability to deliver high quality connectivity. It's a crucial point in terms of IoT (Internet of things) further development: "Technology is still a key driver of experiences nonetheless, in the most advanced venues, no one talks about 'getting' Wi-Fi access anymore, more and more it just happens. This is becoming an expectation now and not seen as much of a value add. At Spurs, over $40 \mathrm{k}$ of their $62 \mathrm{k}$ fans can now stream at any one time" (Nicholas Brice).

For example, the San Francisco Levi's Stadium currently features a 40 gigabit Wi-Fi network, the most powerful in any stadium in the world. The level of "connectivity" of a stadium determined by quality of internet connection. CCS Insight (Market Forecast, 2018-2025) predicts 5G employments and development scenario mirrors of the roll-out of 4G networks. 5G technology promises to accelerate many technological products and services in stadium experiences, such as content uploads/downloads, high-quality video stream, Immersive experiences (VR, $A R$ ), Internet of things (IoT).

\footnotetext{
15 https://postmates.com/

${ }^{16}$ https://www.interticket.com/

${ }^{17}$ https://outsourcing.com/
} 
The 5G Stadium project developed by FC Barcelona and Telefónica has made the Camp Nou the first football stadium in Europe to have dedicated standard 5G coverage. The deployment of this will enable the successful implementation of new immersive ways of accessing sports content from home as if actually being in the stadium ${ }^{18}$.

\section{Conclusion}

The current state of mentioned technologies may still seem to be limited, but has huge potential. The key transformations underlie in dimensions of infrastructure, technologies, services and security solutions. We have outlined 9 main areas of changes in stadium SSCX brought by technologies: multipurpose nature of facilities, modular infrastructure, seating, HVAC, Access, safety and smart ticketing, social media, mobile and immersive experiences, restoration and collaborations, outsourcing, stadium connectivity.

Already, we notice the creation of ambitious new landmark stadiums in the Middle East, Europe and US, while existing facilities across the world are also being completely renovated and upgraded in order to provide their fans with a technologically upgraded experience.

The high quality of internet connection is an essential condition for majority of the discussed above technologies functioning. Mobile apps have become an essential part of sports spectating culture, consolidating all the services and information and functioning for all the stakeholders from connectivity, screens and mobile applications to new technologies like Immersive technologies in the seating and boxes: focusing on "total" experience (Lemon \& Verhoef, 2016) is the new trend in stadiums.

\section{Future directions}

We intend to measure the effect of emerging technologies on in-stadium SSCX quantitatively and qualitatively, referring to customer centric approach. We suggest that use of technologies in SSCX may impact consumer phycology, total experience and satisfaction through different dimensions.

\section{Acknowledgments}

We express our gratitude to Paris Saclay University (France) and Budapest University of Physical Education (Hungary). This work is supported by the ADI 2018 project, funded by IDEX ParisSaclay, ANR-11- IDEX-0003-02 and program "Bourses Mobilité Île-de-France doctorants".

\section{References}

1. Abeza, G., O'Reilly, N., Reid, I. (2013). Relationship Marketing and Social Media in Sport. International Journal of Sport Communication. 6 (2): 120-142. doi:10.1123/ ijsc.6.2.120.

2. Bal, C., Fleck, N. (2016). Connected Stadium: A Pillar for Football Clubs' Marketing Development?. Making a Difference Through Marketing, Springer Singapore, pp.43-58, 2016, 〈10.1007/978-981-10-0464-3_4〉. 〈hal-02292206〉

3. Bee, C., Khale, R. (2006). Relationship marketing in sports: A functional approach. Sport Marketing Quarterly. 15 (2): 102-110.

4. Biscaia R., Hedlund, D.P., Dickson G., Naylor, $M$. (2018). Conceptualizing and measuring fan identity using stakeholder theory, European Sport Management Quarterly, DOI: 10.1080/16184742.2017.1413580

5. Chanavat, N., Bodet, G. (2014). Experiential marketing in sport spectatorship services: A customer perspective. European Sport Management Quarterly, 2014. https://doi.org/10.1080 /16184742.2014.926379

6. Chub, A., Kreizer, I. (2020). Principles of reconstruction of multifunctional stadiums on the example of the Kiev stadium of CSC Armed Forces of Ukraine. IOP Conference Series: Materials Science and Engineering. 907. 012066. 10.1088/1757-899X/907/1/012066.

7. Deutscher, C. Pawlowski, T. (2020). The Impact of Live Broadcasting on Stadium Attendance Reconsidered: Some Evidence from 3rd Division Football in Germany. European Sport Management Quarterly. 10.1080/16184742.2020.1828967.

8. Desbordes, M., Richelieu, A. (2012). Global Sport Marketing: Contemporary Issues and Practice. Routledge, May, 208 p. January 2012.

\footnotetext{
${ }^{18}$ https://www.fcbarcelona.com/en/news/1070481/camp-nou-will-be-the-first-stadium-in-europe-with-dedicated-5g-coverage\#
} 
9. Gentile, C., Spiller, N., Noci, G. (2007). How to sustain the customer experience: An overview of experience components that co-create value with the customer. European Management Journal, 25, 395-410.

10. Gilmore, J. Pine II, B. (2002). Customer experience places: The new offering frontier. Strategy \& Leadership, 30(4), 4-11.

11. Giblin, Tor, \& Parrington (2016). Technology and elite sports performance. A Journal of Mind, Brain \& Culture.

12. Glebova, E. (2020). Définir la réalité étendue dans les sports : limitations, facteurs et opportunités, in Desbordes M., Hautbois C., Management du sport 3.0, Spectacle, fan experience et digital, Economica, 2020.

13. Glebova, E., Desbordes, M. (2020). «Clockwork "Model for Deployment Technologies in Sport Spectators Customer Experiences: Holistic Approach. 28th EASM virtual conference, European Association for Sport Management.

14. Glebova, E., Desfontaine, P. (2020). Sport et technologies numériques: vers de nouvelles expériences spectateur, in Desbordes M., Hautbois C., Management du sport 3.0, Spectacle, fan experience et digital, Economica, 2020.

15. Glebova, E., Desbordes, M. (2021). Technology innovations in sports: Typology, nature, courses and impact, In Ratten, V. (Ed), Innovation and Entrepreneurship in Sport Management, Edward Elgar Publishing, http://dx.doi. org $/ 10.4337 / 9781783473960$

16. Glaser, B. G. \& Strauss, A. L. (1967). The Discovery of Grounded Theory. Strategies for Qualitative Research. Chicago: Aldine. DOI: 10.4236/ce.2011.25061

17. Gulhan, T.F. (2014). Various Types of Advanced Technologies in Sports. IOSR Journal of Sports and Physical Education (IOSR-JSPE) e-ISSN: 2347-6737, p-ISSN: 2347-6745, Volume 1, Issue 6 (Jul-Aug. 2014), PP 01-02

18. Hautbois, C., Djaballah, M., DesbordesM.(2019). The social impact of participativesporting events: a cluster analysis of marathon participants based on perceived benefits, Sport in Society, DOI: 10.1080/17430437.2019.1673371

19. Ha, J-P., Kang S.J., Kim, Y. (2017) Sport fans in a "smart sport" (SS) age: drivers of smartphone use for sport consumption, International Journal of Sports Marketing and Sponsorship,
Vol. 18 Issue: 3, pp.281-297, https://doi. org/10.1108/IJSMS-08-2017-093

20. Jäger, M. (2013). The advent of the fan experience 2.0 through Wi-Fi? The Connected Stadium. Research Report. Sport Facility Management, February 28th, 2013

21. Jeong, M., Lee, M., \& Nagesvaran, B. (2016). Employees' use of mobile devices and their perceived outcomes in the workplace: A case of luxury hotel. International Journal of Hospitality Management, 57, 40-51. DOI:10.1016/j. ijhm.2016.05.003

22. Kaiser, M., Ströbel, T., Woratschek, H., Durchholz, C. (2019). How well do you know your spectators? A study on spectator segmentation based on preference analysis and willingness to pay for tickets, European Sport Management Quarterly, 19:2, 178-200, DOI: 10.1080/16184742.2018.1499790.

23. Klaus, P., Maklan, S. (2012). Towards a Better Measure of Customer Experience. International Journal of Market Research, Volume 55, Issue 2, Pages 227-246.

24. Lee, M., Baker, M. (2017). Technology, customer satisfaction and service excellence. DOI : 10.1079/9781786390677.0083

25. Lemke, F., Clark, M., Wilson, H. (2011). Customer experience quality: An exploration in business and consumer contexts using repertory grid technique. Journal of the Academy of the Marketing Sciences, 39, 846-869.

26. Lemon K.N., VerhoefP.C. (2016). Understanding Customer Experience troughout Customer Journey. Journal of Marketing: AMA/MSI Special Issue, November 2016.

27. McAlexander, J. H., Schouten, J. W., \& Koenig, H. F (2002). Building brand community. Journal of Marketing, 66(1), 38-54. https://doi. org/10.1509/jmkg.66.1.38.18451

28. Melián-González, S., \& Bulchand-Gidumal, $J$. (2016). A model that connects information technology and hotel performance. Tourism Management, 53, 30-37. DOI: 10.1016/j. tourman.2015.09.005

29. Morgan, N. A. \& Rego, L. L. (2006). 'The Value of Different Customer Satisfaction and Loyalty Metrics in Predicting Business Performance', Marketing Science, 25(5), 426-39.

30. Ness H.E. (2016). Spectator experience management at FIA World Rally Championship events. Scientific Forum in Sport Management, SMIJ - VOL. 12, Number 2, 2016. 
31. Schut, P., Glebova, E. (2020). Typology of Roland Garros Mobile Application 2018 Users, 28th EASM Conference, Virtual, European Association for Sport Management, September 2020.

32. Shank, M.D. (2005). Sports Marketing: A Strategic Perspective. Pearson Prentice Hall, 2005 - Business \& Economics.

33. Sheth, J. N. (2002). The future of relationship marketing. Journal of Services Marketing. 16 (7): 590-592.

34. Steward B., Smith, A.T.C., Nickolson, M. (2003). Sport Consumer Typologies: A Critical Review. Sport Marketing Quarterly, vol.12, Nov.4, 2003.

35. Ritchy, D. (2017). Security Innovation in U.S. Bank Stadium, Where Technology Is King, Security Magazine, 2017. Retrieved from: https:// www.securitymagazine.com/

36. Solberg, H. (2014). Hosting major sports events: The challenge of taming white elephants. Leisure Studies. 33.

37. Tharenou, P., Donohue, R., Cooper, B. (2007). Management Research Methods. Cambrige University Press, 2007. ISBN: 9780521694285

38. Thompson, A., Potter L.E. (2017). Proposing Augmentation of Live Sporting Events with Gamification and Social Sharing. OzCHI 2017, Nov 28 - Dec 1, Brisbane, Australia, Human Nature. ACM ISBN 978-1-4503-5379-3/17/11. https://doi.org/10.1145/3152771.3156174

39. Troacă, V., Bodislav D. (2012). Outsourcing. The Concept. Theoretical and Applied Economics. Volume XIX (2012), No. 6(571), pp. 51-58, https://EconPapers.repec.org/RePEc:agr:journl:v :6(571):y:2012:i:6(571):p:51-58

40. Yu, K., Trail, G (2011). A conceptual framework for understanding relationships between sport consumers and sport organizations: A relationship quality approach. Journal of Sport Management. 25 (1): 57-69. doi:10.1123/jsm.25.1.57.

41. Zaki, M, Neely, A. (2018). Customer Experience Analytics: Dynamic Customer-Centric Model. Handbook of Service Science, Volume II, Publisher: Springer, Retrieved from: https://www. researchgate.net/publication/328342137_ Customer_Experience_Analytics_ Dynamic_Customer-Centric_Model/ stats

\section{Web references}

- https://www.stadiummanagers.org/

- https://attstadium.com/

- https://www.sc.qa/en/stadiums

- https://www.fifa.com/worldcup/qatar2022/

- https://tkhsecurity.com/case/ kyocera-stadium-ado-den-haag/

- https://adodenhaag.nl/en/

- https://www.usbankstadium.com/

- https://www.vikings.com/news/u-s-bankstadium-views-on-high-tech-camerassoar- 15930234

- https://sc.qa/en/stadiums/lusail-stadium

- https://3ddigitalvenue.com/platform/ ticketing $3 \mathrm{~d}$

- https://www.fcbarcelona.com/en/

- https://www.levisstadium.com/

- https://www.uefa.com/insideuefa/ football-development/innovation-hub/

- https://postmates.com/

- https://www.oculus.com/

- http://fcbusiness.co.uk/

- https://outsourcing.com/

- https://mercedesbenzstadium.com/

- https://www.interticket.com/

- https://www.scisports.com/

- https://www.sportsbusinessdaily.com/ Conferences-Events/2019/SFF.aspx

- https://horizonsummit.com/

- https://www.iqpc.com/ events-worldstadiumcongress

- https://www.telefonica.com/en/home

\section{Abbreviations used:}

- AR - Augmented reality

- CRM - Customer Relations Management

- CX - Customer Experiences

- FC - Football club

- XR - Immersive technologies

- IoT - Internet of Things

- MR - Mixed reality

- SSCX - Sports Spectators Customer

Experiences

- VR - Virtual reality 